\title{
Analysis of Income Diversification and Livelihood Strategies Among Pastoral and Agro-pastoral Households' in Southern Ethiopia
}

\author{
Algaga Balense ${ }^{1}$, Sisay Debebe ${ }^{2, *}$ \\ ${ }^{1}$ Department of Economics, College of Business and Economics, Arba Minch University, Arba Minch, Ethiopia \\ ${ }^{2}$ Department of Economics, College of Business and Economics, Addis Ababa University, Addis Ababa, Ethiopia
}

Email address:

sisaydebebe2000@gmail.com (S. Debebe)

${ }^{*}$ Corresponding author

To cite this article:

Algaga Balense, Sisay Debebe. Analysis of Income Diversification and Livelihood Strategies Among Pastoral and Agro-pastoral

Households' in Southern Ethiopia. Journal of Investment and Management. Vol. 9, No. 3, 2020, pp. 72-79. doi: 10.11648/j.jim.20200903.12

Received: July 17, 2020; Accepted: August 6, 2020; Published: September 8, 2020

\begin{abstract}
In pastoral and agro-pastoral areas of Ethiopia, apart from farming engaging on non-farm and/or off-farm income earning activities or diversifying income-earning means lie at the heart of livelihood strategies among pastoral and agropastoral household in southern Ethiopia. This study analyses determinant of the level of income diversification and livelihood strategies of pastoral and agro-pastoral households' in southern Ethiopia. In order to select representative sample a combination of both stratification and random sampling techniques were used and selected 196 household heads. To analyze the data simple descriptive statistics, Multivariate Probit, and Two-limit Tobit models were employed. The result of model reveals that factors influencing the use of livelihood strategies are age, sex, family size, educational level, farm size, market distance to the main market, livestock holding size, cooperative membership, use of credit and access to transport were as sex, family size, educational level, livestock holding size, crop failure, a distance of nearest main market income from farm and share of non \& off-farm income influenced income diversification. The government should emphasize strengthening the agricultural production system with due attention to identified factors influencing both diversification of income and livelihood strategies and thereby enhancing the well-being of pastoral and agro-pastoral households of the area.
\end{abstract}

Keywords: Livelihood Strategies, Income Diversification, Multivariate Probit, Two-limit Tobit Models, Southern Ethiopia

\section{Introduction}

Ethiopia is among the top fastest-growing economy in Sub Saharan Africa and, its economy mainly bases on the agriculture sector. It contributes about $34 \%$ of total Gross Domestic Product (GDP) and more than $70 \%$ of total employment opportunities, $70 \%$ of the raw material requirements for local manufacturing industries, and about $70 \%$ of total export $[15,22]$. However, the contribution of the agriculture sector is not as expected due to rain-fed farming system which is vulnerable to environmental and climaterelated shocks. In addition, the sector also characterized by subsistence farming with decreasing farm sizes, lower productivity and less use of modern agricultural technologies $[11,20]$. As a result, the contribution of the sector for poverty reduction and enhancement of food security is limited over the last years. However, widening livelihood diversification choices and diversification of income source supplement the effort of food insecurity and poverty reduction in rural Ethiopia particularly in pastoralist areas.

Ethiopian pastoralists and agro- pastoralist inhabits the largest livestock population in Africa and more than $61 \%$ of its area [18]. They raise a large portion of the national herd, estimated about $42 \%$ of the cattle, $7 \%$ of the goats, $25 \%$ of the sheep, $20 \%$ of the equines [19]. The county is among the top holder of various livestock species in the world [8]. The sub-sector contributes to the food supply in terms of meat and dairy products. The contribution of export of meat, live animals, and animal products increased from 11.4 percent of the total value of export in 2004/5 to 13 percent in 2015 . However, livestock production has declined its contribution to the aggregate economic growth by 5.8 percent per annum 
from $2004 / 5$ to $2015 / 16$ similarly declined its share to total agricultural output by 23.6 percent during the same time [17]. Despite such resource potential and export market opportunity, its productivity has to decrease over from time to time due to various reasons.

According to the information from the South Omo zone, pastoralist, and agro-pastoralists live in harsh physical conditions with risk climatic regimes. Due to feed the shortage for the farmers, mobility is considered as key characteristics of pastoralist and agro-pastoralists which enable them to withstand diverse environmental-related shocks over the last years in the area. However, in recent years, various empirical studies explains the incidence of climate change overtime increased the frequency of drought, rainfall variability, and the incidence of new livestock diseases, change of land use pattern, degradation of natural resources and declining agricultural yield in pastoralist and agro-pastoralists areas of southern Ethiopia [1, 7, and 9]. As a result, it undermines the mitigation and adaptation strategies of food insecurity and poverty among pastoralist and agropastoralist household head's of the study area.

One of the solutions for pastoralist and agro-pastoralists to cope up and develop the resilience of food insecurity and poverty is through enlarging with diverse livelihood strategy choices through engaging with multiple activities such as agriculture farming and widening the source of non-farm income, off-farm income activities and diversifying the level of income earning means [3, 15 and 4]. Moreover, enhancing the productive capacity of an asset holding means can also be used as additional strategies for alleviation of poverty, food insecurity and improve the livelihood of citizens in rural Africa like Ethiopia [5].

In the previous empirical literature, there are various studies that examined determinants of livelihood diversification in rural Ethiopia. Some of recent studies on determinants of income diversification in rural Ethiopia [4, 9, 12, 148 and 25]. However, studies on both determinants of livelihood strategy and income diversification together are limited in Ethiopia particularly in pastoralist and agropastoralists areas [5]. Such studies may help to identify the constraints and challenges related to the widening of livelihood strategy options and income diversification thereby helps for the development of policy recommendations. Therefore, this study aims to identify the factors influencing the level of income diversification and livelihood strategies among pastoralist and agro-pastoralists households in Malle District of South Omo zone, southern Ethiopia.

\section{Materials and Methods}

\section{Description of Study Area}

The study was conducted in Malle district of south Omo Zone, southern Ethiopia. It is one of the eight rural districts found in South Omo Zone that is characterized by pastoralist and agro-pastoralists areas. The district lie with an area of $1,432 \mathrm{~km}^{2}$ and the total population comprises men $(50.6 \%)$ and women (49.4\%) [6]. According to the information obtained from the district office, Malle is found $799 \mathrm{~km}$ southern from Addis Ababa in southern Ethiopia. The mean Rainfall ranges between $400-1200 \mathrm{~mm}$ mean annual temperature $28.5^{\circ} \mathrm{C}$. The altitude of the district ranges between 501-1440 m.a.s.l, and located at 5 $5^{\circ} 0^{\prime} 0^{\prime \prime}-60^{\circ} 0^{\prime} 0^{\prime \prime} \mathrm{N}$ with the longitude of $36040^{\prime} 0$ " E - 37010'0"E latitude [6].

Data Types and Methods of Data Collections

The study used both primary and secondary data sources. Primary data were collected from the sample by using structured questionnaire, key informant interviews, and focus group discussion. In addition, secondary data were collected through consulting various literature and official government reports pertaining to the livelihood strategies and income diversification of the study area.

Sampling Technique and Sample Size Determination

A multi-stage sampling technique was used to select sample pastoralist and agro-pastoralist households. In the first stage, stratification based on agroecology was made. The study classified into highland and low land areas. In the second stage, after 2 kebeles (lowest administrative unit) out of 6 agro-pastoral high land kebeles were selected and 2 kebeles out of 6 pastoral low land kebeles were selected using random sampling proportion to their total population size. In the third stage, a total of 196 agro-pastoral and pastoral households were randomly proportion to their total size was selected and interviewed. The sample size was determined based of Yamane sample size estimation formula [23].

\section{Method of Data Analysis}

In order to analyze the data, combinations of the descriptive statistics, Multivariate Probit model, Simpson diversity index and two-limit Tobit econometrics model were used and detail specification with their justification is provided in sub-sequent section:

A. Multivariate Probit model: In a single equation econometrics model such as binary Probit mode, information on a farmer's use of one livelihood strategy does not alter the likelihood of adopting other livelihood strategies at a time. However, a simultaneous econometrics model such as the Multivariate Probit model estimates several correlated binary outcomes jointly by allowing for the potential correlation between unobserved disturbances and the relation between the use of different livelihood strategies. Failure to capture unobserved variables and their interrelationships among different rural livelihood strategies lead to bias and inefficient parameter estimates [13]. The model specified as;

$$
\begin{gathered}
Y_{1 i}=X_{1}^{\prime} \beta_{1 i}+\varepsilon_{1 i} \\
Y_{2 i}=X_{2}^{\prime} \beta_{2 i}+\varepsilon_{2 i} \\
Y_{3 i}=X_{3}^{\prime} \beta_{3 i}+\varepsilon_{3 i} \\
Y_{1 i}=X_{4}^{\prime} \beta_{4 i}+\varepsilon_{4 i}
\end{gathered}
$$

Where $Y_{j i}$ is represent strategies that adopted by the $i^{\text {th }}$ 
household head, $(i=1,2,3$ and 4 are farming, non-farm income, petty trade business and off farm income, respectively), to are the respective vectors of covariates determining the endogenous variables to represents a vector of unknown parameters to be estimated and error terms. The error terms of Multivariate Probit Model (MVP) follows distributed normally with a mean of zero and variancecovariance matrix $\mathrm{V}$, where $\mathrm{V}$ has values of 1 on the diagonal

matrix and zero correlations among off-diagonal elements. The MVP model is specified as;

$$
\left(\begin{array}{l}
\varphi_{1} \\
\varphi_{2} \\
\varphi_{3} \\
\varphi_{4}
\end{array}\right) \sim\left(\begin{array}{l}
0 \\
0 \\
0 \\
0
\end{array}\right)\left(\begin{array}{cccc}
1 & \rho_{12} & \rho_{13} & \rho_{14} \\
\rho_{21} & 1 & \rho_{22} & \rho_{23} \\
\rho_{31} & \rho_{32} & 1 & \rho_{34} \\
\rho_{41} & \rho_{42} & \rho_{43} & 1
\end{array}\right)
$$

Where $\emptyset_{1}$ to $\emptyset_{4}$ are correlated disturbances MVP; $\rho^{\prime} s$ are correlations between endogenous variables.

Assuming that every outcome is a success, the probabilities that enter the likelihood function of the simulation are explained as:

$$
\left.\begin{array}{rl}
\operatorname{Probability}\left(Y_{1 i}^{*}=1 Y_{2 i}^{*}=1, Y_{3 i}^{*}=1, Y_{1 i}^{*}=1, Y_{2 i}^{*}=1\right) & =\Psi_{2}\left(X_{1}^{\prime} Y_{1 i}^{*}, X_{2}^{\prime} Y_{2 i}^{*}, X_{3}^{\prime} Y_{3 i}^{*}, X_{4}^{*} Y_{4 i}^{*}, \rho\right) \\
& =\operatorname{Pr}\left(\varphi_{1 i} \leq \beta_{1}^{\prime} X_{1}, \varphi_{2 i} \leq \beta_{2}^{\prime} X_{2}, \varphi_{3 i} \leq \beta_{3}^{\prime} X_{3}, \varphi_{4 i} \leq \beta_{4}^{\prime} X_{4}, \varphi_{5 i}\right.
\end{array}\right\}
$$

Where $\emptyset$ is the multivariate normal density function.

A. Measurement of Income Diversification Level: The forms of income diversification used by the pastoralist and agro-pastoralist households were determined by income diversification index using the Simpson Index of diversity which measures the shares of the respective farm household's income derived from various sources [2]. The income diversification index is given as:

$$
S I D=1-\sum_{i}^{n} P_{i}^{2} \text { and } P_{i}=\frac{K}{\sum K_{i}}
$$

Where SID is the Simpson Diversity Index, $\mathrm{n}$ is the total number of income sources, $P_{i}$ represent $i^{\text {th }}$ income proportion of $i^{\text {th }}$ household head and $\mathrm{K}$ is $i^{\text {th }}$ income and $\sum \mathrm{K}_{\mathrm{i}}$ is the total income of $\mathrm{i}^{\text {th }}$ household head.

B. The two-limit Tobit model: is a censored regression model and used when the decision to diversify income and its extent are assumed to be jointly determined by the same variables. Beside, the Two-limit Tobit model is appropriate when the observations in the data set bounded between 0 to 1 values. Simpson Index of diversity of income is also truncated bounded between 0 and 1 and hence the use of this model is well justified. Following Green the model specified as [13]:

$$
Y_{i}=\left\{\begin{array}{lll}
L & \text { if } & Y_{i}^{*} \leq L \\
Y_{i}^{*} \text { if } & L \quad L<Y^{*}<\mathrm{U} \\
U \text { if } & Y_{i}^{*} \geq U
\end{array}\right.
$$

Where $Y_{i}$ is the observed dependent variable, in this case Simpson diversity index of household $i$ (unobserved for values $\leq 0$ and $\geq 1$ ) and $\mathrm{L}=$ lower limit $\mathrm{U}=$ upper limit.

The likelihood function of this model is specified as:

$$
\mathrm{L}\left(\beta, \delta \mid Y_{i} X_{i} L_{1 i} L_{2 i}\right)=\pi_{Y_{i}-L_{1 i}} \varnothing\left(\frac{L_{1 i}-\beta^{\prime} X_{i}}{\delta}\right) \pi_{Y_{i}=Y_{i} Y_{i}^{*}} \emptyset\left(\frac{Y_{i}-\beta^{\prime} X_{i}}{\delta}\right) \pi_{Y_{i}-L_{i}} \emptyset\left(\frac{L_{2 i}-\beta^{\prime} X_{i}}{\delta}\right)
$$

Where $\mathrm{L}_{1 \mathrm{i}}=0$ (lower limit) and $\mathrm{L}_{2 \mathrm{i}}=1$ (upper limit) are normal and standard density functions

McDonald and Moffitt (1980) proposed useful decomposition techniques of total marginal effects. Based on

the likelihood function of the model stated in equation (9), the total marginal effect divided into the three marginal effects as follows: The unconditional expected value of the dependent variable:

$$
\frac{\partial E\left(Y_{i}\right)}{\partial X_{i}}=\left[\varnothing\left(Z_{U}\right)-\emptyset(Z l)\right] \frac{\partial E\left(Y_{i}\right)}{\partial X_{i}}+\frac{\partial\left[\emptyset\left(Z_{u}\right)-\emptyset\left(Z_{1}\right)\right]}{\partial X_{i}}+\frac{\partial\left(1-\emptyset\left(Z_{u}\right)\right.}{\partial X_{i}}
$$

The expected value of the dependent variable conditional upon being between the limits

$$
\frac{\partial E\left(Y^{*}\right)}{\partial X_{i}}=\beta k\left(1+\frac{\left\{Z_{1} \varnothing\left(Z_{1}-Z_{u} \emptyset\left(Z_{u}\right)\right\} 2\right.}{\left\{\varnothing\left(Z_{u}\right)-\varnothing Z_{1}\right\}^{2}}-\left[\frac{\left.\left\{\varphi\left(Z_{1}\right)-\varphi Z_{u}\right)\right\}^{2}}{\left\{\varphi\left(Z_{u}\right)-\varphi\left(Z_{1}\right)\right\}^{2}}\right.\right.
$$

The probability of being between the limits:

$$
\frac{\partial\left[\emptyset\left(Z_{u}-\emptyset\left(Z_{1}\right)\right]\right.}{\partial X_{i}}=\frac{\beta k}{\delta}\left(\varnothing\left(Z_{1}\right)-\emptyset\left(Z_{U}\right)\right.
$$


Where $\varphi$ is the cumulative normal distribution, $\varnothing$ is the normal density function, $Z_{1}=\frac{-\beta \prime x}{\delta}$ and $Z_{u}=\frac{(1-\beta x)}{\delta}$ are standardized variables that came from the likelihood function given the limits of yi, and $\delta$ is the standard deviation of the model. Based on the review of previous empirical literatures, Table 1 below explains the definitions of variables, measurement and expected hypothesis.

Table 1. Summary statistics and description of continues and categorical variables.

\begin{tabular}{|c|c|c|c|c|c|c|}
\hline \multirow{2}{*}{ Variables } & \multirow{2}{*}{ Mean /\% } & \multirow{2}{*}{ Std. Dev } & \multirow{2}{*}{ Min } & \multirow{2}{*}{ Max } & \multicolumn{2}{|l|}{ Expected sign } \\
\hline & & & & & Livelihood strategy & Income diversification \\
\hline Age in years & 41.9 & 12.8 & 21 & 76 & - & - \\
\hline Family size in adult equivalent & 6.4 & 2.4 & 1.8 & 15.6 & + & + \\
\hline Farm size in hectare & 0.71 & 0.53 & 0 & 3 & + & + \\
\hline Livestock in TLU & 11.6 & 9.7 & 0 & 33.2 & - & + \\
\hline Market distance from home in $\mathrm{KM}$ & 7.4 & 0.15 & 0.15 & 27 & - & + \\
\hline Farm experience in years & 18 & 12.7 & 3 & 50 & - & - \\
\hline Share of non/off-farm income in Birr & 0.33 & 0.28 & 0 & 1 & + & + \\
\hline Simpson diversity index & 0.28 & 0.3435 & 0 & 0.74 & & \\
\hline Sex (male) & 86 & & & & + & + \\
\hline Access of transport & 39 & & & & _- & - \\
\hline Use of fertilizer & 28.6 & & & & + & + \\
\hline Use of improved seed & 34.2 & & & & - & - \\
\hline Residing agro-ecology - highland & 67 & & & & - & + \\
\hline Crop failure & 83.1 & & & & & \\
\hline
\end{tabular}

Source: Survey data, 2019.

\section{Result and Discussions}

\section{Determinants of Livelihood Strategies Choice Model Result}

This section examines the factors influencing household head's decisions to use combinations of four livelihood strategies choices. The commonly employed livelihood strategies in the study area are engaging in farming, off-farm income, non-farm income activates, and small petty trade activities that are mainly used by agro-pastoralist and pastoralists households heads and the result of multivariate Probit model presented in Table 2 below. The result shows that the correlation coefficients of error terms are statistically significant at $1 \%$ indicating that livelihood strategy choices are complementarities among themselves. Moreover, Likelihood ratio test statistics of Wald (56) value of 150.79 of the model indicate that there is a significant joint correlations and statistically significant at $1 \%$ levels, justifying estimation of the Multivariate Probit that considers the power of significance of explanatory variables on dependent variables.

The result of the model further indicates that the null hypothesis that there is no correlation between residual of four equations $\rho_{21}=\rho_{31}=\rho_{41}=\rho_{32}=\rho_{42}=\rho_{43}=0$ is not rejected. This implies that household's decisions to implement more than one livelihood strategies are not strictly independent. The correlation value of $\rho_{31}$ and $\rho_{42}$ are statistically significant at $5 \%$ and $10 \%$ significance level, respectively suggesting separate chooses of livelihood strategies from both non-farm and off-farm income livelihood strategies are not implemented in the study area. Therefore, the use of a multivariate Probit model is justified due to the fact one or more livelihood strategies are not mutually exclusive in the study area.

Age of household head has negatively and significantly influencing the probability of participation non-farm livelihood strategy at $10 \%$ level of significance. This negative result implies that younger household heads implement non-farm income livelihood strategy then older aged household head due to the fact that older household head lack physically strength to deploy their labor for additional since non-farm activates. This result is similar with pervious study by Baharu Gebreyesus [4] in their respective studies. Moreover, male household heads as compared with female has positively and statistically affected the probability of participation farming livelihood strategy at $5 \%$ statistical significance level. The positive sign could be justified due to the fact that agricultural activities require physical strangeness by its nature.

Family size of household head has positively and statistically significance effect on the probability of participation to farming, non-farm, petty trade and off-farm livelihood strategies at $5 \%, 10 \%, 10 \%$ and $1 \%$ significance level, respectively. The result indicates that large families are more likely to practice on multiple farming activities due to the fact that they will rectify the shortage of because of labor to undertake different activates as a time. This result is also consistent with the finding of Yirga Chilot [25] in his study.

Educational level of household head has positively and statistically influencing on the probability of participation of non-farm and petty trade strategies at $5 \%$ and $10 \%$ statistically significant level, respectively. The result could be justified due to the fact that educated household heads gains the required skills and knowledge that enables them to 
involve in non-farm income activates and various business activities.

Farm size of household heads has positively and significantly influencing the probability of agricultural framing livelihood strategy at $5 \%$ significance level. Whereas, negatively affected the probability of non-farm and petty trade livelihood strategies at $1 \%$ significance level. The positive relationship of farm land size with likelihood of agricultural farming livelihood strategy implies that farmers who have large farm size are spending more time on the farm cultivations and producing agricultural outputs compared with those who have small area of land on the other hand, non-farm and petty trade livelihood strategies are not demanding land size.

Livestock size has positively and statistically influencing the probability of participation to farming and off-farm livelihood strategies at $10 \%$ and $5 \%$ level of significances, respectively. This positive result indicates that household head that have more livestock size might use income from livestock rearing for strengthening farming and off-farm activities.

Access to transport of household head has positively and statistically influencing on the probability of participation of farming strategy at $1 \%$, petty trade and off- farm income strategies at $5 \%$ statistically significant levels. The result could be justified due to the fact that household head who have access to transportation are more likely to participate in farming, petty trade and off-farm livelihood strategies than those who did not have access which is due to the fact that transport facilities marketing of goods and services.

Farming experience of household head has positively and statistically significance effect on the probability of participation to farming and non-farm livelihood strategies at $5 \%$ significance levels. The result indicates that experienced household head are more likely to practice on multiple farming activities due to the fact that they realize its benefit and accumulated the required skills of managing various activities at a time.

Table 2. Multivariate Probit model result for determinants of livelihood strategies choices.

\begin{tabular}{|c|c|c|c|c|}
\hline \multirow{2}{*}{ Variables } & Farming strategy & Non-farm income strategy & Petty trade strategy & Off-farm income strategy \\
\hline & Coefficients & Coefficients & Coefficients & Coefficients \\
\hline Age & 0.008 & $-0.013 *$ & -0.008 & 0.006 \\
\hline Sex & $0.521 * *$ & -0.123 & 0.087 & 0.329 \\
\hline Family size & $0.070 * *$ & $0.482 *$ & $0.057^{*}$ & $0.162 * * *$ \\
\hline Educational level & -0.018 & $0.325 * *$ & $0.444 * * *$ & 0.192 \\
\hline Farm size & $0.064 * *$ & $-0.432 *$ & $-0.508 *$ & -0.186 \\
\hline Livestock size & $0.025^{*}$ & -0.032 & .0292 & $0.035 * *$ \\
\hline Access to transport & $0.547 * * *$ & 0.362 & $0.625 * *$ & $0.623 * *$ \\
\hline Use of fertilizer & 0.307 & -0.237 & -0.134 & 0.110 \\
\hline Use of Improved seed & 0.281 & -0.236 & -0.207 & -0.129 \\
\hline Farming experience & $0.028 * *$ & $-.0324 * *$ & -0.019 & -0.012 \\
\hline Agro-ecology & -0.094 & 0.003 & 0.338 & $0.368^{*}$ \\
\hline Cooperative membership & $0.548 * *$ & 0.338 & $0.338 *$ & 0.001 \\
\hline Use of credit & -0.690 & 0.006 & $0.579 * *$ & $0.257^{*}$ \\
\hline Wald chi ${ }^{2}(56)$ & $150.79 * * *$ & & & \\
\hline
\end{tabular}

Note $*, * *$ and $* * *$ statistical significant level at $1 \%, 5 \%$ and $10 \%$, respectively.

Source: Model result, 2019.

Agro-ecology has positively and statistically influencing the probability of participation to off-farm livelihood strategies at $10 \%$ level of significance. This positive result indicates that household head who reside their living in high land area have more likely to participate in off-farm livelihood strategy compared with households who residing in the low land agro-ecology areas. The possible reason is that in the lowland (pastoral) area there is limitation of encouraging opportunities such as resource limitation, low access to infrastructure, low access to transportation, and long distance to main market centers compared to agropastoral household those residing in high land areas.

Cooperative membership status of household head has positively and statistically significance effect on the probability of participation to farming and petty trade livelihood strategies at $1 \%$ and $5 \%$ significance level, respectively. The result indicates that household head who are a member of cooperative have more likely to participate in farming and also on petty trade livelihood strategies than those who did not. This positive result suggesting that farmer cooperative would provide the required supported for farming and petty trade activates.

The of use of credit by household head has positively and statistically influencing on the probability of participation of petty trade at $5 \%$ and off- farm income strategies at $10 \%$ statistically significant levels. The positive result could be justified due to the fact that household head who used credit from rural financial institution are more likely to participate in petty trade and off-farm livelihood strategies than those who did not used which is due to the fact that engaging to other livelihood strategies needs finance. This result of this study is also agrees with finding of rural livelihood diversification in west Bengal [8].

II. Determinants of Income Diversification Model Result 
Two-limit Tobit model was employed to identify factors influencing the status and level of income diversification among pastoral and agro-pastoral households' farmers and results are presented in Table 3. The likelihood ratio statistics with a value of 81.77 statistically significant at $1 \%$ levels of significance indicate that the independent variables are simultaneously influencing the dependent variable and hence the model has good explanatory power. Further, the model result show that all coefficients of the variables hypothesized to influence income diversification have the expected sign and of the twelve variables included in the model, eight are found to have statistically significant effects and the remaining four variables are found to have no statistically significant effect.

Sex of household head has positive and significant influence on the level of income diversification at $10 \%$ level of significance. This implies that female headed household heads are less likely to diversify their income than male headed household heads in the study areas. This might be due to the fact that female-headed households in agro-pastoral community are usually endowed with less resource and less access to participate on off-farm income activates due to the influence of culture. As a result, being male headed household head increases the probability of income diversification by 4.8 percent. This result agrees with the prior finding on rural farm households' income diversification [12].

Family size in the household has positive and significant influence on the level of income diversification at $10 \%$ level of significance, indicating that household head with more family size are more likely to diversify their income than others. The possible explanation for this result is that income diversification needs to engage in various non-farm and offfarm income activities at a time which might requires more family labor. As a result, an increase in family size by one family member in adult equivalent leads to a 16.2 percent increase in the probability of income diversification. The relationship between family size and income diversification was reported to have a similar result in earlier studies by Ibrahim and Onuk [14].

Table 3. Tow-limit Tobit model result for determinants of income diversification.

\begin{tabular}{llll}
\hline Variables & Coefficients & Std. Err. & Marginal Effect \\
\hline Age & -0.002 & 0.002 & -0.0010 \\
Sex & $0.073^{*}$ & 0.043 & 0.0481 \\
Family size & $0.016^{*}$ & 0.009 & 0.0103 \\
Educational level & $0.036^{* *}$ & 0.015 & 0.0334 \\
Farm size & 0.098 & 0.061 & 0.0546 \\
Livestock size & $0.008^{* *}$ & 0.003 & 0.0087 \\
Crop failure & $-0.126^{* *}$ & 0.056 & -0.01162 \\
Main market distance & $-0.018^{* * *}$ & 0.004 & -0.0885 \\
Access to transport & -0.069 & 0.052 & -0.0450 \\
Farm experience & 0.006 & 0.005 & 0.0039 \\
Farm income & $0.127 * * *$ & 0.028 & 0.0852 \\
Share of non \& off farm income & $0.172 * *$ & 0.068 & 0.1129 \\
Constant & $0.439 * * *$ & 0.119 & \\
Log likelihood & -63.854918 & & \\
LR chi ${ }^{2}(12)$ & $81.77^{* * *}$ & & \\
\hline
\end{tabular}

Note: $* * *$ and $* * *$ at $10 \%, 5 \%$ and $1 \%$ statistical significance levels, respectively.

Source: Model result, 2019.

Education level of the household head has positive and significant effect on the level of income diversification at $5 \%$ level of significance, implying that the likelihood of income diversification increases with household head with more formal education level. The possible reason is that higher educational qualification tends to open more employment opportunities for income generation activities due to the fact that education has a power for making people to be aware of more opportunities for generating income from different sources. On average, each additional year of education of the household head increases the probability of income diversification by 3.3 percent. This result is similar with study made by Baharu Gebreyesus [4] and Eneyew Adugna [9] in their similar respective studies.

Livestock holding size has positive and significant influence on the level of income diversification at 5\% level of significance, indicating that household head with large number of livestock are more likely diversify income than others. The possible reason is that household with relatively more livestock make use of the income obtained from livestock for expanding non-farm income activities. A unit increase in the TLU leads to an increase in the probability of income diversification by 0.87 percent.

Crop failure has negative and significant relationship with the level of income diversification at $5 \%$ of significance level, indicating that household head that face crop failure are less likely to diversify income than those who are not. This is because farmers who face crop failure during the cropping season might not get necessary income for expanding nonfarm income activities. That indicates that household who faces crop failure during the cropping season has decreased the probability of income diversification by $1.16 \%$ as compared with household who did not face crop failure.

Distance from main market has negative and significant relationship with the level of income diversification at $1 \%$ significance level, this indicates that household head who are 
far away from market centers are less likely to diversify income source than those who are closer. This is because household head who are far away from main market centers face greater transaction and transport costs, and lacks incentive in participation various activities. One more $\mathrm{km}$ walking distance to the main market center decreases the probability of diversifying income by 5.8 percent. A study by Eneyew Adugna [9] and Yenesew et al. [24] also found a similar result while the result contradicts with the finding of Baharu Gebreyesus [4].

Farm income has positive and significant relationship with the level of income diversification at $1 \%$ level of significance. The positive result of income obtained from farm suggests that household head who obtained relatively large income from both crop and livestock production diversify income than those who have less income. The possible reason is that those household head who obtain sufficient income from farming have more likely to overcome financial constraints and hence engaging in alternative income-generating activities. The result shows that each additional one birr from farm income increases the probability of household head to diversify income by $8.5 \%$. Similarly, household head who has obtained more income has from the share of non-farm and off-farm income has a positive and significant relationship with income diversification at 5\%statistical significance level. This result implies that each additional increase of the share of non/offfarm income in $\%$ increases the probability of household head to diversify income by $11 \%$. The implication of this is that increase in the share of non/off-farm income would increase income diversification.

\section{Conclusion and Recommendations}

The livelihood of pastoral and agro-pastoral society does not only depend on rearing of livestock and crop production, but it also relays on different survival activities that substitute the accumulation of additional capital. While agriculture remains is the backbone of the study farmers, but farmers looking for different livelihood strategies to minimize the adverse effects of natural disasters. Livelihood strategies and income diversification sources have provided as one the main coping strategy for the attainment of food security and reducing poverty in the study area. But, there are different factors influencing both livelihood strategies and income diversification of households in the study area. Determinants of livelihood and income diversification of the study area cannot be focused only on the agriculture sector alone. Therefore, the regional and local governments should put more emphasis on strengthening the agriculture sector along with providing due attention for enlarging various opportunities of livelihood strategies and income diversification sources among agro-pastoralists of the study area.

Moreover, the result suggests that policy and strategy makers should expand formal educational opportunities, ensuring gender equality mainstreaming through strengthening women's assets, socio, economic and political empowerments, strengthening livestock production system by widening converges of veterinary services and disseminating high-yielding breeds of livestock's, strengthening farmer's cooperative formation by building office and warehouse store in each district, construction of the road that connected to the main outlet market, laborsaving technologies and enraging income opportunities obtained from both farm and share of non-farm income should be made. Finally, the local and regional the government should encourage diversification of livelihood strategies options through expanding the provision of rural financial instruction so that enlarging livelihood diversification income sources options would be made among pastoral and agro-pastoral areas of the study area.

\section{Acknowledgements}

This work was supported by ministry of science and higher education of Ethiopia under grant of Master of Science program in agricultural economics at school of post graduate program of Arba Minch University, Ethiopia.

\section{References}

[1] Anna, C. R. (2002). "Rural household strategies in southern Mali": Determinants and contribution of income diversification to income level and distribution. World Bank working paper 2785: 1-203 www.worldbank/anna.

[2] Ashebir D and Negussie Z. (2015). Determinants of Participation in the Rural Non farm Economy in Eastern Ethiopia. Journal of Economics and Sustainable Development. 6 (23); 9-20.

[3] Ayalneh, B. (2002). Poverty profile and livelihood diversification in Rural Ethiopia: Implication to poverty reduction, Konrad, Hagedorn.

[4] Baharu Gebreyesus. (2016). Determinants of Livelihood Diversification: The Case of Kembata Livelihood Diversification: Journal of Poverty, Investment and Development. Vol 23, pp 1-10.

[5] Barrett, Christopher B. and Reardon, Thomas and Webb, Patrick (2001). Nonfarm Income Diversification and Household Livelihood Strategies in Rural Africa: Concepts, Dynamics and Policy Implications. Food Policy, Vol. 26, No. 4, 2001. Available at SSRN: https://ssrn.com/abstract=1847711.

[6] CSA (Central Statistical Authority). (2013). Population projection of Ethiopia for all regions at Wereda Level from 2014 to 2017. Federal Democratic Republic of Ethiopia Central Statistical Authority, Addis Ababa, Ethiopia.

[7] Demisse, D. and Workneh, N. 2004. Determinants of rural livelihood diversification: Evidence from Southern Ethiopia. Quarterly Journal of International Agriculture V 43 No: 209267.

[8] Dilruba, K. and Belderbos R (2012). Rural Livelihood Diversification in West Bengal: Determinants and Constraints. Journal of Agricultural Economics Research Review, 25 (1): 115-124. 
[9] Eneyew Adugna (2012). Determinants of Livelihood Diversification in pastoral societies of Southern Ethiopia. Journal of Agriculture and Biodiversity Research. 1,(3), 4352; retrieved on October 2015.

[10] FAO (2018). FAOSTAT. United Nations Food and Agriculture Organization, Room. http://faostat.fao.org/ (accessed 15, January 2018).

[11] FDRE. (2011). Federal Democratic Republic of Ethiopia Country strategy paper (2011-2015). Addis Abeba: African Development Bank Group.

[12] Gecho Yishak (2017). Rural Farm Households' Income Diversification: The Case of Wolaita Zone, Southern Ethiopia. Social Sciences. 6 (2) 45-56. doi: 10.11648/j.ss.20170602.12.

[13] Greene, W. 2012. Econometric Analysis, $6^{\text {th }}$ Edition. Upper Saddle River, NJ: Prentice-Hall.

[14] Ibrahim, H. I., \& Onuk. (2009). Analysis of Rural Non-farm Diversification among Farming Households in Doma area of Nasarawa State, Nigeria. Publication of Faculty of Agriculture, Nasarawa State University, Keff. 5 (1): 49-54 Online copy available at www.patnsukjournal.net/currentissue.

[15] IMF (2018). http://imf.org/en/countries/ETH.

[16] McDonald JF, Moffitt RA (1980). The Use of Tobit Analysis. Review on Economics and Statistics 62 (3): 18-320.

[17] National Bank of Ethiopia (NBE) (2017). Annual Report 2015/16, Addis Ababa, Ethiopia.

[18] PFE. (2008.). Pastoralist Forum Ethiopia. Millennium
Development Goals and Pastoral Development. Addis Ababa: Proceedings of the $4^{\text {th }}$ National Conference on pastoral development in Ethiopia.

[19] PFE. (2010). Pastoralist Forum Ethiopia, et al. Pastoralism and land: Land tenure, administration and use in Pastoral areas of Ethiopia.

[20] Sisay D, H. J, D. Goshu and K. E. Abdi. 2015. Speed of improved maize seed adoption by smallholders' farmers in south-western Ethiopia: Analysis Using the Count Data Models. Journal Agricultural Economics, Extension and Rural Development, 3 (5): 276-282.

[21] Wooldridge, J. (2002). Econometric analysis of cross section and panel data. London, UK.: MIT Press.

[22] World Bank (2018). Ethiopia Economic Update: The Inescapable Manufacturing services Nexus: Exploring the potential of distribution services. Electronic Journal of Agricultural and Developmental Economics 1 (2): 168-83.

[23] Yamane, T. (1967). Statistics: an Introductory Analysis, 2nd Ed. New York: Harper and Row.

[24] Yenesew, S. Y., Eric, N. O., and Fekadu, B. (2015). Determinants of livelihood diversification strategies: The case of smallholder rural farm households in Debre Elias Woreda, East Gojjam Zone, Ethiopia. African Journal of Agricultural Research, 10, 1998-2013. doi: 10.5897/AJAR2014.9192.

[25] Yirga Chilot. (2007). The Dynamics of Soil Degradation and Incentives for Optimal Management in Central Highlands of Ethiopia. PhD dissertation, University of Pretoria, South Africa. 